\title{
燃料電池運転状態診断方法の研究* (FFTによる解析の高速化と診断の可能性検討)
}

\author{
許 斐 敏 明*1, 佐 保 勇*2
Research on Diagnosis Technique on PEFC Running Condition
(High Speed Analysis by FFT and Feasibility Study of Diagnosis) \\ Toshiaki KONOMI*3 and Isamu SAHO \\ ${ }^{* 3}$ Department of Mechanical Engineering Science, Kyushu University, \\ 6-10-1 Hakozaki, Higashi-ku, Fukuoka-shi, Fukuoka, 812-8581 Japan

\begin{abstract}
Real time analysis on impedance spectroscopy in PEFC (Polymer Electrolyte Fuel Cell) is tried using FFT (Fast Fourier Transform) method. It is proved this method can analyze the Cole $\cdot$ Cole plots of PEFC with high speed and high accuracy compared to conventional FRA (Frequency Response Analyzer). PEFC is simulated to equivalent circuit model with four resistances and three capacitances, and effects of running condition on those are analyzed by experiment. Results show this method has capability of on-board diagnosis and fuel cell system control.
\end{abstract}

Key Words: Polymer Electrolyte Fuel Cell, Diagnostics, FFT, Electrochemistry, FRA, AC Impedance Spectroscopy, Equivalent Circuit, Over Voltage Diagnosis

\section{1. 粕}

近年の環境保全への関心の高まりとともに，内燃機 関に替わる自動車用の動力源として環境負荷が低い固 体高分子形燃料電池(以下 PEFC)が注目されている. 水素を燃料とした PEFC は水しか排出しないゼロエ ミッション動力源であるため, 現在開発が推進されて いる.

その一方で, 実用化に向けての課題も多い. その一 つが運転状態の診断方法が確立されていないことであ る. 自動車用 PEFC は複数セルを直列に接続したス タック構成で使用される. 運転中に何らかの原因でセ ルの一つに不具合が生じると, スタック全体の性能が 低下するのみならず，そのセルに致命的な損傷を与え ることがある. この不具合を回避するためには, セル の運転状態の変化を瞬時にとらえて, 診断・制御する 必要がある.

* 原稿受付 2004 年 3 月 22 日。

*1 正員, 九州大学大学院工学研究院 (-812-8581 福岡市東区 箱崎 6-10-1)

*2 学生員, 九州大学大学院工学府

E-mail : konomi@mech.kyushu-u.ac.jp
燃料電池セル全体を電気等価回路に置き, 抵抗値 と容量值を同定する交流インピーダンス法(1)が電気 化学分野では用いられてきており, 計測が容易で精 度に優れる FRA(Frequency Response Analyzer) ${ }^{(1)}$ が普 及している. しかしその測定には各周波数の正弦波 を一つずつ掃引していくため時間がかかり, 刻々と 変化する PEFCの運転状態を実時間で計測するのに は適していない.

そこでオンボードでの瞬時診断に適用できる可能 性がある広帯域 FFTインピーダンス解析法(1)に着目 した. 広範囲の周波数のランダム波形を一度に重畳 させることにより, 短時間での測定が可能と考えら れる.

FFTインピーダンス解析法の計測時間と解析精度 の関係を実験により明らかにし, 精度を維持しつつ 高速化の方策を探ることとした．また運転条件を変 化させた時のインピーダンスの変化を調べて，この 方法での診断の可能性を検討することとした. 


\section{2. 円Tによるインピーダンス測定法}

電極界面挙動を線形並進不変な系と仮定すると, 刺 激信号 $e(t)$ と応答信号 $i(t)$ との関係は, 線形応答理 論によりインパルス応答関数 $h(t)$ にって記述でき る. (1)

$$
i(t)=h(t) * e(t)
$$

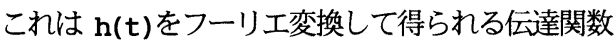
H(f)によっても表される.

$$
\begin{aligned}
& I(f)=H(f) \cdot E(f) \\
& \text { ここで } \\
& I(f)=\int_{-\infty}^{\infty} i(t) e^{-j 2 \pi f t} d t, \\
& H(f)=\int_{-\infty}^{\infty} h(t) e^{-j 2 \pi f t} d t, \\
& E(f)=\int_{-\infty}^{\infty} e(t) e^{-j 2 \pi f t} d t
\end{aligned}
$$

であるが，いくつかの周波数に対する分散を測定し たい場合, “多重化の利点”を利用して刺激信号に次 式のような正弦波の重畳を考える.

$$
e(t)=\sum_{k} A_{k} \exp \left\{j\left(2 \pi f_{k} t+\theta_{k}\right)\right\}
$$

$\theta_{\kappa}$ は各周波数に対する位相で, $\theta_{\kappa}$ が 0 から $2 \pi$ までランダムに割り振られているときは白色雑音をあ らわす. $\mathrm{A}_{\kappa}$ は各周波数に対する重みである. この応 答は次式で表される.

$$
i(t)=\sum_{k} A_{k} H\left(f_{k}\right) \exp \left\{j\left(2 \pi f_{k} t+\theta_{k}\right)\right\}
$$

$\mathrm{H}\left(\mathrm{f}_{\kappa}\right)$ を求めるためフーリ工変換を行うと,

$$
\begin{aligned}
& I\left(f_{k}\right)=A_{k} H\left(f_{k}\right) e^{j \vartheta_{k}}=H\left(f_{k}\right) \cdot E\left(f_{k}\right) \\
& H\left(f_{k}\right)=I\left(f_{k}\right) \cdot E^{*}\left(f_{k}\right) /\left\{E\left(f_{k}\right) \cdot E^{*}\left(f_{k}\right)\right\}
\end{aligned}
$$

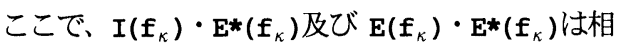
互相関関数および自己相関関数である. これより, 電 極系アドミッタンスは $\mathrm{H}(\mathrm{f})$ で, インピーダンスは $\mathbf{H}(\mathbf{f})^{-1}$ で表される.

\section{3. 实䀫装}

燃料電池セルの性能評価には図 1 に示す実験装置 を用いた. 東陽テクニカ社製のガス供給装置と電子

負荷器（Scribner 社製 890C）, Electro Chem 社の PEFC (反応面積 $5 \mathrm{~cm}^{2}$ ，拡散層は撥水処理あり），

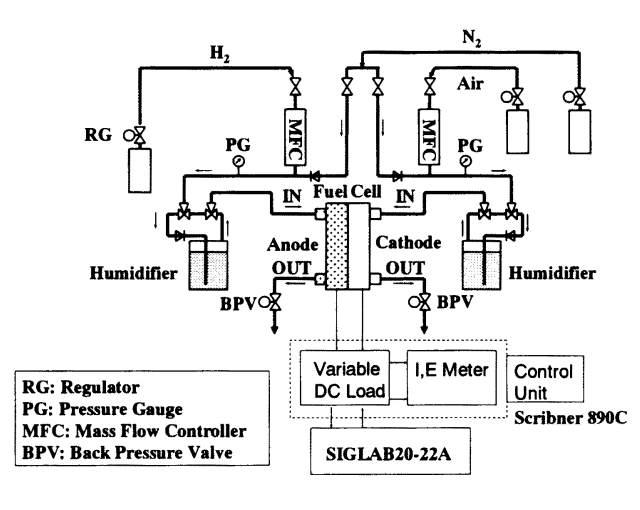

Fig.1 Experimental apparatus

それに FFT（Spectral Dynamics 社製 Siglab20-22A）で 構成される．供給ガスは，アノードには $99.95 \% \mathrm{H}_{2}$ を， カソードには乾燥空気をそれぞれ高圧ボンべから供給 した. ガス供給装置によってセルに入るガスの温度を, またセルに組み込んだ温度調節器によってセルの温度 を調節できるようになっている. 加湿器を出た直後の 供給ガスはその温度での飽和水蒸気状態であり, セル 温度との兼ね合いによりセル内部でのガス湿度を調節 することができる. また背圧弁によりセル内部の圧力 を変えることができる，電子負荷器によって任意の一 定負荷をかけた状態で，FFT により広帯域ノイズ信 号を重畳させ，インピーダンスを測定する.

\section{FFT 法, FRA 法の解析精度, 速度の比校}

\section{1 電気回路のインピーダンス測定}

FFT インピーダンス法の解析精度, 解析時間を FRA 法と比較するために, PEFC の最も単純な等価 回路である図 2 の電気回路をカーボン皮膜抵抗とコン デンサーにより作成した. 抵抗值とコンデンサ一容量 はそれぞれ，供試然料電池セルの $10^{6}, 10^{6}$ 倍を選定し， 回路の時定数を一致させた. そして LCR 測定器によ り回路構成要素個々の抵抗值, 容量値を測定した結果, $\mathrm{R} 1$ は $31.7 \mathrm{k} \Omega, \mathrm{R} 2$ は $189.5 \mathrm{k} \Omega, \mathrm{C} 1$ は $0.339 \mu \mathrm{F}$ であ った．この值を最確値とする．FRA を用いた交流イ ンピーダンス法, そして FFT を用いたインピーダン ス法によってこの回路の Cole・Cole プロットを作成 し，この図から回路の抵抗値とコンデンサー容量を求 める. これらの值を LCR 測定器による最確值と比較 し誤差を求める. さらに FRA 法と FFT法の測定に要 した時間を比較する. 


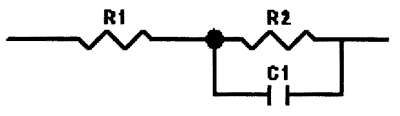

$\mathrm{R} 1: 31.7 \mathrm{k} \Omega$

$\mathrm{R} 2: 189.5 \mathrm{k} \Omega$

$\mathrm{C} 10.339 \mu \mathrm{F}$

Fig.2 Electrical cincuit

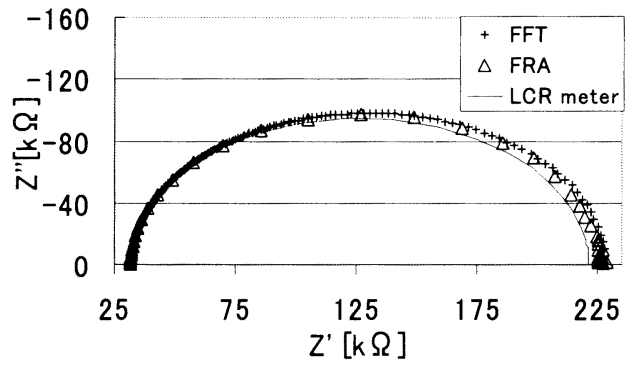

Fig.3 Cole $\cdot$ Cole plots of electrical circuit by FFT, FRA

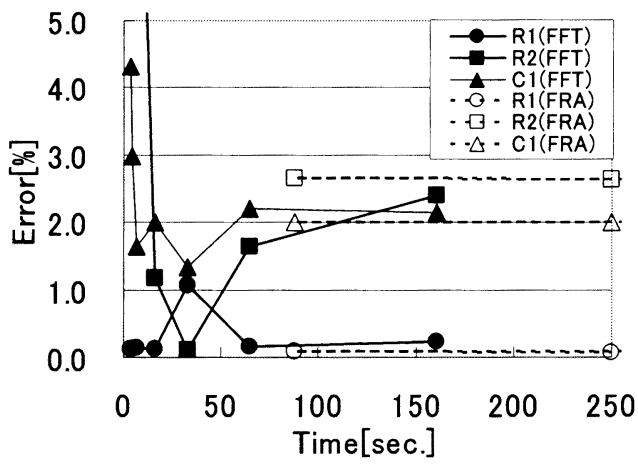

Fig.4 Speed and accuracy by FFT, FRA

図 2 の電気回路において FFT，FRA それぞれを用 いて Cole・Cole プロットを測定した結果を図 3 に示 す. LCR 測定器による R1, R2, C1 実測値を用いた計 算カーブが最確值である． FFT，FRA による Cole・ Cole プロットはほぼ同じ值を示しており，低周波側で 最確值からわずかに低周波側にずれている.

図 4 に LCR メー夕測定値を最確値とし, FFT, FRAによる Cole・Cole プロットから求めた R1, R2, C1 の誤差を綎軸に，そのときの解析時間を横軸に示す。 FRA は各周波数においてそれぞれ 1 回の測定を行つ た通算時間であり, FFT は 1 回の測定は $0.5 \sim 8$ 秒程 度だが，個々のデー夕にはばらつきがあった. 数回の 平均化を実施したので，その測定帯域幅，積算回数に より所要時間が変わっている. 図4 の結果では計測時 間 20 秒 70 秒間では FFT のほうが良好な精度が得 られた. 80 秒以上では同一となった.

\section{Pのインピータンス測定}

3章に示した実験装置と PEFC を用いて FFT, FRA それぞれによる Cole・Cole プロットを測定した結果 を図 5 に示す，PEFCの運転条件はセル，水素，空気 のバブラー出口温度はすべて $80^{\circ} \mathrm{C}$ (飽和水蒸気を供給), 水素と空気のストイキ比(実流量理論流量，0.6A/ $\mathrm{cm}^{2}$ 時) はそれぞれ 10, 負荷電流密度 $0.2 \mathrm{~A} / \mathrm{cm}^{2}$, 背圧(セ儿内部 圧力) $0.1 \mathrm{MPa}$ (ゲージ圧力)である. 同図において極低 周波域を除いて，両者は同じ測定結果となっている. また，FRA による測定において，極低周波数域では 測定値にばらつきが見られる.これは低周波時の測定 にかなりの時間を要し，その間にセル内で何らかの状 態変化, 例えば通路のフラッディングによる出力電圧 の急激な低下等が発生し，その影響がインピーダンス の乱れとして計測されたと考えられる. FFT による 測定の場合, 測定が短時間であるためにこのような乱 れを含む確率が小さくなる. また測定中に状態変化が 発生した場合には, 低周波側だけでなく全周波数域で 変化をとらえることができる.

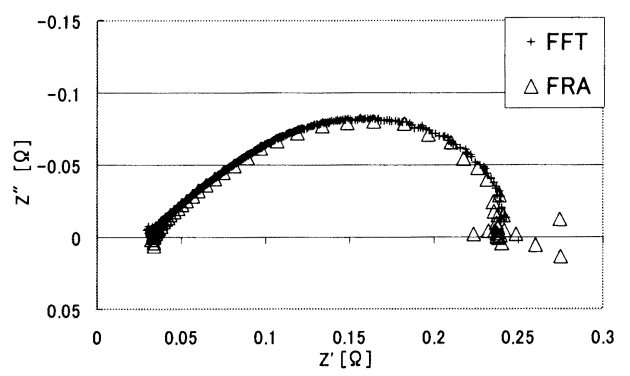

Fig.5 Cole • Cole plots of PEFCby FFT, FRA

\section{5.正枟条件かインピータンスに与える影雪の解析}

\section{1 解析方法と等価回路の逞定}

実測 $\mathrm{Cole} \cdot \mathrm{Cole}$ プロットに, 等価回路に適した各 抵抗值と容量値を与えたときの Cole・Cole 計算力ー ブを重ねることによって, セルのインピーダンスの各 要素の値を推定していく.

この解析に用いる等価回路の要素数を検討した．図 2に示した最も単純な $\mathrm{R} 1, \mathrm{R} 2, \mathrm{C} 1$ 回路(3要素)では, 各 要素の物理的意味を解釈することが難しい，また，実 測値と計算カーブの誤差が大きいことが予想される.

過電压解析では，燃料電池セルの各部抵抗をアノー ド過電圧 $\left(\eta_{\mathbb{R}}\right)$, 直流抵抗による過電圧 $\left(\eta_{\mathbb{R}}\right), \cdot$ 力 ソード過電圧 $\left(n_{\mathrm{c}}\right)$ の三つ( 5 要素)に分解する解析例 がある. このときの等価回路を図 6 に示す. 要素の物 理的意味の解积が容易になると予想される. さらに, 
カソード過電圧 $\left(\eta_{\mathrm{c}}\right)$ をカソード活性化過電圧

$\left(\eta_{0}\right)$ とカソード濃度過電圧 $\left(\eta_{\text {Q }}\right)$ に分解する(7 要 素)(例ももある.

要素数と実測值に対する計算カーブの一致度を実験 と比較した結果を図 7 に示す. 予想通り，3要素では カーブフィッテング精度がかなり悪くなっている. 検 討した三つの等価回路では 7要素が最も精度が良く, 要素の物理的意味の解釈が容易であるので, この回路 を用いることにより実験結果の解析を行うこととする.

各要素の物理的意味との対応は下記のように行った.

(1) 高周波数での実軸切片における推定インピーダン ス值 R2 をセルの直流抵抗( $(\mathrm{R})$ とする.

（2）抵抗值が最も小さい $\mathrm{C}, \mathrm{R}$ 並列回路をアノード抵 抗と推定する. 図6では R1, C1 とする.

（3）抵抗值が最も大きい C, R 並列回路をカソード活 性化抵抗と推定する. 図6では R3, C2 とする.

（4）抵抗值が中間の C, R 並列回路をカソード濃度抵 抗と推定する. 図6では R4,C3 とする.

実験条件を変化させた時の各要素の推定計算值の 変化の傾向から上記の仮定がどの程度妥当であるか, 運転状態の診断をどの程度可能とするかを以下の実 験で検討することとする.

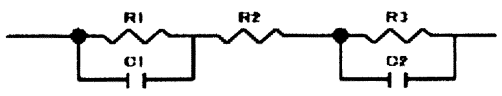

(a) 5 Components;

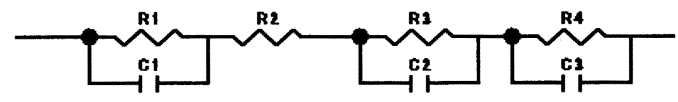

(b) 7Components;

Fig.6 Equivalent circuits of $\mathrm{PEFC}$

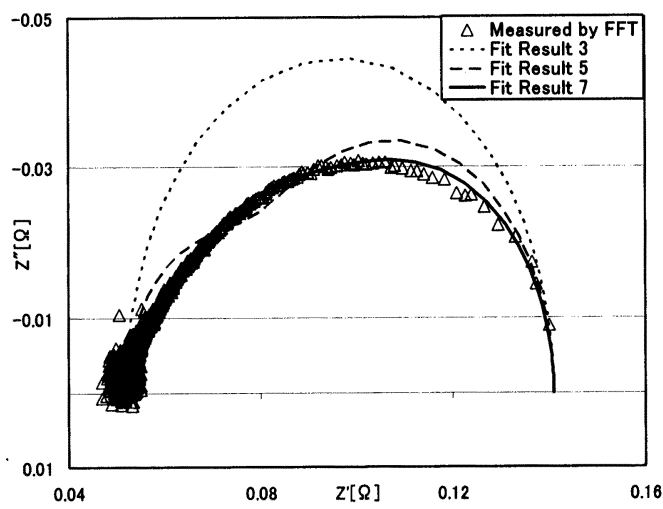

Fig.7 Cell impedanoe and fitcurves of each equivalent circuit
Table 1 Experimental conditions

\begin{tabular}{|l|c|c|c|}
\hline Condition pattern & I & II & III \\
\hline Cell temperature $\left[{ }^{\circ} \mathrm{C}\right]$ & $40,50,60,70,80$ & 80 & 80 \\
\hline Gas Temperature[ $\left[{ }^{\circ} \mathrm{C}\right]$ & $40,50,60,70,80$ & 60 & 80 \\
\hline Gas Stoichiometric rate & 10 & $23,5,10$ & 10 \\
\hline
\end{tabular}

\section{2 实的策件}

実験条件を表 1 に示す. 電流密度 $0.2 \mathrm{~A} / \mathrm{cm}^{2}$, セル内 部圧力 $0.1 \mathrm{MPa}$ はすべての条件において一定である. セル温度, ガス温度, ガス流量を変化させてその運転 条件を変化させる. ストイキ比は 4.1 項に示したよう に電流密度が $0.6 \mathrm{~A} / \mathrm{cm}^{2}$ のきを基準にしている.

\section{3 实験拮果およひ考察}

\section{1 通枟温度の得}

運転条件 I，すなわちセル温度とガス温度を等しく 設定しつつ(飽和水蒸気供給状態), 両者の温度を同時 に変化させた. 負荷電流密度は全ての実験において $0.2 \mathrm{~A} / \mathrm{cm}^{2}$ である. 図 8(B)右端に運転温度とこのときの出 力電圧を示す. 運転温度の低下とともに出力電圧も低 下している. Cole・Cole プロットは図 8 のように, プ ロットの高周波側は変化していないが, 低周波側が低 温になるにつれて大きくなっている.

これを 5.1 項に示した解析方法で各要素の抵抗值を 計算した結果を図 9 に示す. 同図からわかるように, 温度低下により R3 だけか影著な増加を示しており, R1, R2, R4 の抵抗值が微增している.

図 10 に各要素の容量值の計算結果を示す. 温度低 下により， R3 と並列をなす $\mathrm{C} 2$ (カソード活性化抵抗 並列容量と推定)が大きく減少し, R4 と並列をなす C3(カソード濃度抵抗並列容量と推定)が増加している. 以上の結果から, 運転温度の低下によるカソード側の 触媒活性の低下が R3 を増加させ, C2 を減少させた と考えられる.

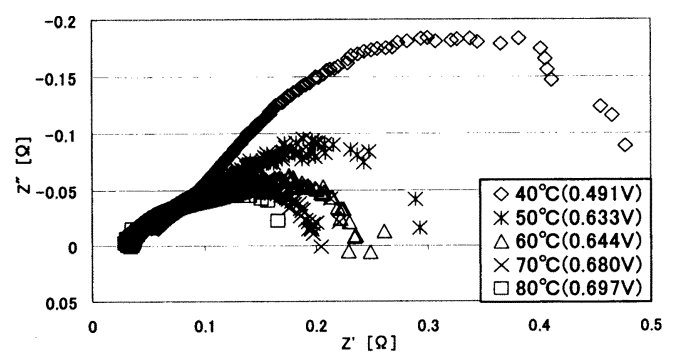

Fig.8 Effects of running temperature on Cole $\cdot$ Cole plots 


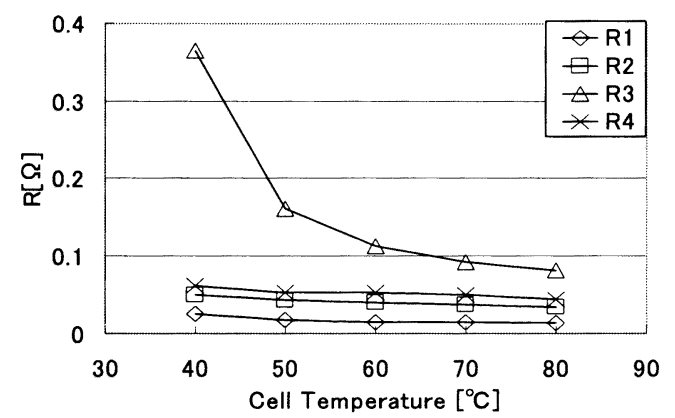

Fig.9 Effects of running temperature on resistances

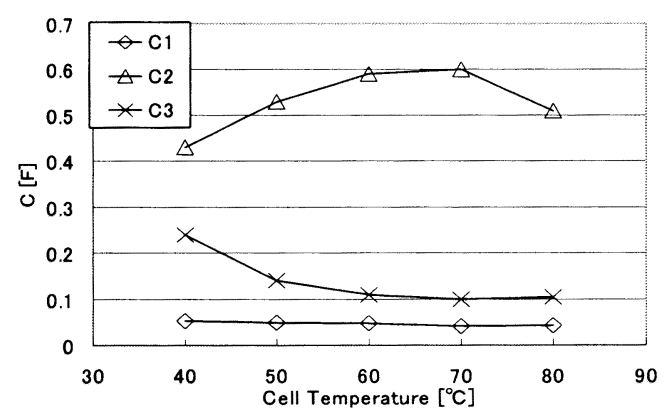

Fig.10 Effects of running temperature on capacitances

\section{2 供拾水素, 空気のストイキ比の影}

図 11 は運転条件II, すなわちセル内での供給水素, 空気の相対湿度が $42 \%$ の状態で, ストイキ比を変化 させた場合のインピーダンスの変化を表す. ストイキ 比を大きくすると Cole・Cole プロットカーブが右方 に平行移動する変化を示しており, 直列抵抗(R2)の変 化か顕著であることを示唆している.

図 12 に抵抗值の変化を示す. ストイキ比の増加と ともに R2が増加し, 他の抵抗值は変化を示さない.

図 13 にストイキ比を増加させた時の容量値の変化 を示す. C2 のみがストイキ比 2 から 5 までの間, 大 きく減少し, その後は一定值を示している. 他の容量 值に変化は見られない.

供給水素, 空気が飽和以下のやや渇き気味の場合, 生成水による MEA, 拡散層等の湿潤化が重要である. ストイキ比を必要以上に高く設定すると生成水が供給 ガスにより外部に持ち出されて MEA 等の保水量が減 少することとなり, 直列抵抗 R2 が増加したと考えら れる.

MEA 等の保水量の減少か膜の部分的な乾きを生じ させ, その部分の抵抗值が大きくなってカソード活性 化の機能を部分的に失った場合は反応面積の減少を生

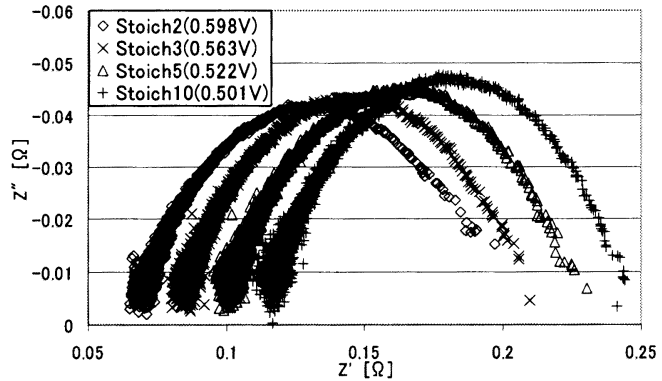

Fig.11 Effects of stoichiometric rate on Cole $\cdot$ Cole plots

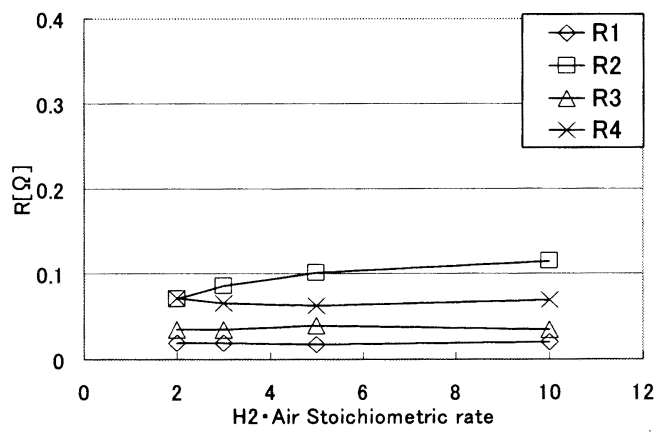

Fig.12 Effects of stoichiometric rate on resistanoes

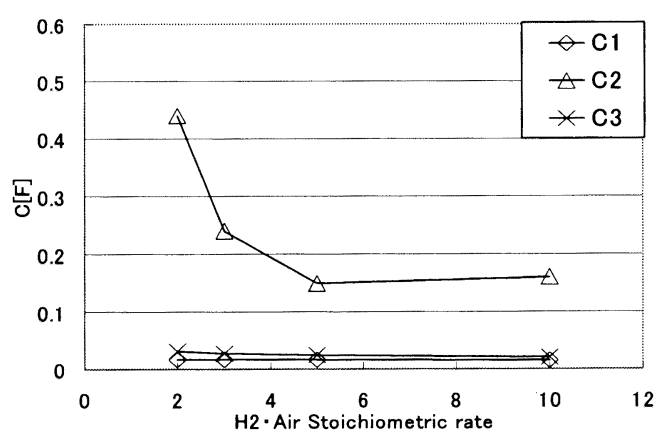

Fig.13 Effects of stoichiometric rate on capacitances

じる可能性がある. このことが C2 を減少させている と推定される.

\section{3 同一条件下での出力低下の原因訅断}

PEFC を複数回稼動させると，たとえまったく同じ 運転条件でも, 必ずしも一定の出力が得られるわけで はない. それは何らかの原因により内部過電圧か湾化 し, 取り出される起電力に影響を与えるためである. 表1のIIIに示す, 同一運転条件において出力電圧が異 なる時の Cole・Cole プロットを比較したのが図 14 で ある. 出力電圧が低下すると高周波側は変化せずに, 
低周波側に向かってプロットカーブが大きくなる傾向 を示している.

図 15 に抵抗值の変化を示す. 出力電圧が低いと R3 のみが増加し，他の抵抗值は変化していない．

図 16 に容量值の変化を示す. 出力電圧が低いと, R3 に並列に配置された $\mathrm{C} 2$ の久が減少し, 他の容量 はわずかに增加する傾向を示している.

水蒸気飽和状態のガスを流している実験条件であり, 負荷電流密度が $0.2 \mathrm{~A} / \mathrm{cm}^{2}$ と小いこと, ストイキ比が 10 と大きいことから, 通路のフラッディングは生じ ず，生成水による挔散層内の部分的なフラッディング

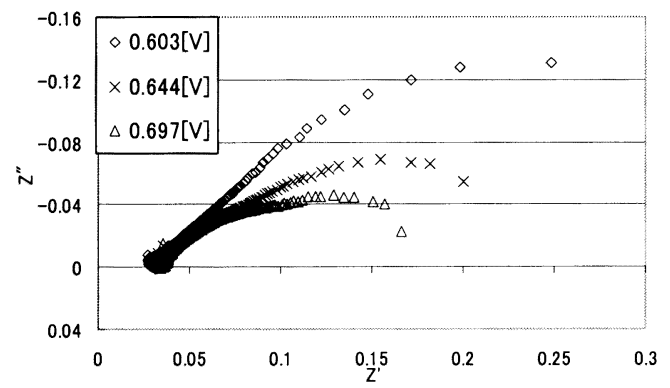

Fig.14 Effects of cell voltage drop on Cole $\cdot$ Cole plots

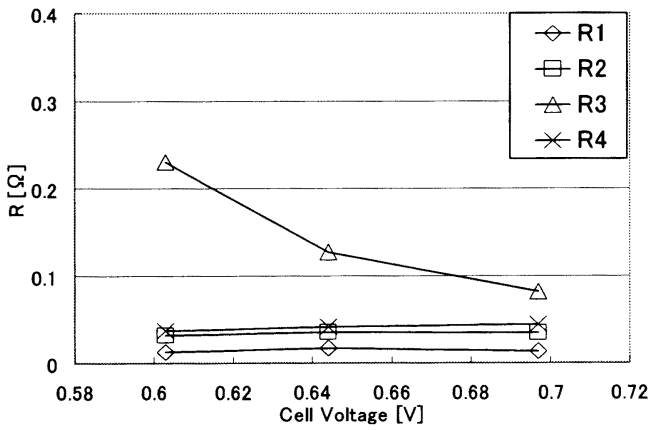

Fig.15 Effects of cell voltage drop on resistances

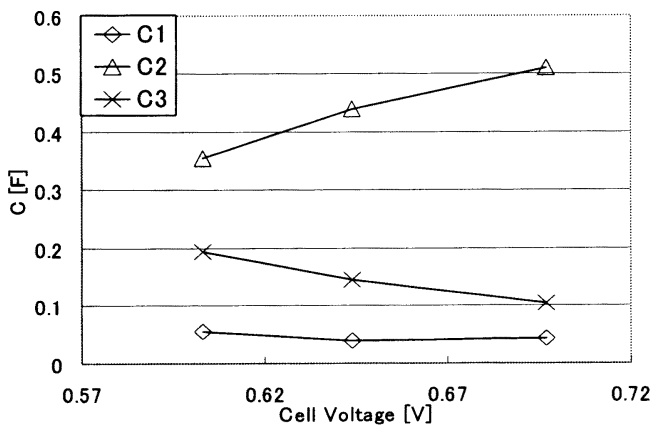

Fig.16 Effects of cell voltage drop on capacitanoes
のみが生じる可能性がある，この場合，MEA 上で機 能しない部分が生じ，反応面積が減少することが考え られる. すると C2 は減少し，C2 の減少により R3が 増加する可能性がある.

運転条件 II(ストイキを変化させる)では，図 12,13 に示したように，C2 が減少したにもかかわらず R3 は変化せず，図 15,16 とは異なった結果となっていた. 供給ガスの湿度により結果が異なっており，今後更な る追究が必要と考えている.

\section{6. 結 言}

FFT によるインピーダンス解析の高速化と燃料電 池の運転状態を変化させた時のインピーダンスの変化 を実験により調べて，下記の知見を得た。

(1) FFTによるインピーダンス解析は, 従来の FRA (Frequency Response Analyzer) を用いた正弦波掃引法 と比較して, 高速, 高精度の解析が可能である.

(2) 燃料電池の各部抵抗を 4 個の抵抗と 3 個の容量 の等価回路に置き, 運転条件がこれらの要素に与える 影響を実験し，以下の結果を得た。

(1)PEFC の運転温度を変えると, カソードの活性化 に起因すると推定される変化が検出される.

(2)供給水素と空気のストイキ比を大きくすると， MEA の部分的な乾きに起因すると推定される変化が 検出される.

(3)同一運転状態での出力電圧変化は, 拡散層等の部 分的なフラッディングに起因すると推定される変化が 検出される.

この手法は㜣料電池運転状態のオンボード診断と制 御に利用できる可能性がある.

\section{文 献}

（1）逢坂哲彌 - 小山昇 - 大坂武男, 電気化学法 基礎測定マニュアル，（1989），157，講談 社サイエンティフィク.

（2）竹中啓恭，燃料電池技術とその応用，(2000), 92, テクノシステム. 